\title{
ANALISIS KINERJA SIMPANG BERSINYAL SECARA TEORITIS DAN PRAKTIS
}

\author{
Risna Rismiana Sari \\ Staf Pengajar Jurusan Teknik Sipil Politeknik Negeri Bandung Jl. Gegerkalong Hilir Ds.Ciwaruga \\ Bandung 40012. Email: risna_28@yahoo.com
}

\begin{abstract}
ABSTRAK
Yogyakarta merupakan salah satu kota besar di Indonesia yang mengalami pertumbuhan pesat. Kota ini terkenal sebagai kota pelajar dan budaya karena mempunyai banyak institusi pendidikan. Daerah Simpang Jetis adalah salah satunya. Simpang ini merupakan salah satu simpang empat bersinyal di Yogyakarta yang memiliki arus lalulintas cukup padat karena merupakan jalur untuk menuju ke berbagai universitas dan sekolah di sekitar kawasan simpang. Penelitian ini dilakukan untuk mengevaluasi kembali kinerja Simpang Jetis yang terdapat di lapangan saat ini dan membandingkan dengan prediksi dari perhitungan berdasarkan MKJI 1997. Analisis yang dilakukan meliputi arus jenuh, waktu siklus, kapasitas dan derajat kejenuhan serta perilaku lalulintas. Dari hasil analisis, didapatkan perbedaan nilai dari hasil observasi dan prediksi. Perbedaan ini dikarenakan berbedanya faktor penyesuaian dan kondisi yang dipertimbangkan. Dalam analisis berdasarkan MKJI 1997, analisis didasarkan pada kondisi lalulintas ideal yang sesuai dengan peraturan. Tetapi yang terjadi di lapangan tidak selalu demikian. Maka nilai analisis hasil obsevasi dianggap lebih dapat digunakan untuk dijadikan bahan evaluasi terhadap kondisi simpang karena data dan analisis didasarkan pada kondisi sebenarnya di lapangan.
\end{abstract}

Kata kunci: simpang, arus jenuh, siklus, kapasitas, derajat kejenuhan, perilaku lalulintas, MKJI 1997

\section{Pendahuluan}

Jalan merupakan suatu prasarana perhubungan darat yang dipergunakan untuk lalulintas angkutan orang maupun barang dari suatu daerah dengan daerah yang lainnya. Seiring dengan bertambahnya jumlah penduduk maka kepemilikan dan penggunaan kendaraan ikut meningkat terutama di daerah perkotaan. Hal ini akan mempengaruhi pertumbuhan dan perkembangan kegiatan manusia terutama pada kawasan yang memiliki prosentase yang tinggi seperti daerah kegiatan komersial dan pendidikan.

Simpang Jetis merupakan pertemuan dari ruas Jl. AM. Sangaji - Jl. Prof. Dr. Sarjito dan Jl. W. Monginsidi. Simpang ini merupakan salah satu simpang empat bersinyal di Yogyakarta yang memiliki arus lalulintas cukup padat karena merupakan jalur untuk menuju ke berbagai universitas dan sekolah di sekitar kawasan simpang. Kemacetan pada simpang juga sering terjadi terutama pada saat jam sibuk yang mengakibatkan antrian yang cukup panjang. Dengan berbagai kondisi tersebut, maka sangat perlu dilakukan evaluasi kembali tentang kinerja simpang dengan berbagai hambatan dan pengaruh dari aktivitas disekitarnya.

\section{Studi Pustaka}

1. Arus Lalulintas Jenuh

Arus lalulintas jenuh adalah arus lalulintas maksimum yang dapat melewati persimpangan dengan lampu lalulintas. Untuk arus lalulintas jenuh dasar dapat dihitung dengan menggunakan rumus empiris:

$$
S_{0}=600 \times W e
$$

dimana:

$S_{0} \quad=$ arus jenuh dasar

We = lebar efektif jalan

Arus lalulintas jenuh didapatkan dari hasil perkalian antara arus jenuh dasar dengan berbagai faktor penyesuaian untuk berbagai kondisi seperti yang dapat diihat pada persamaan 2 .

$S=S_{0} \times F_{C S} \times F_{S F} \times F_{G} \times F_{P} \times F_{R T} \times F_{L T}$

dimana: 
$S \quad=$ arus jenuh

$S_{0} \quad=$ arus jenuh dasar

$F_{C S} \quad=$ faktor penyesuaian ukuran kota

$F_{S F} \quad=$ faktor penyesuaian hambatan samping

$F_{G} \quad$ = faktor penyesuaian kelandaian

$F_{P} \quad=$ faktor penyesuaian parkir

$F_{R T} \quad=$ faktor penyesuaian belok kanan

$F_{L T} \quad=$ faktor penyesuaian belok kiri

\section{Karakteristik Sinyal Lalulintas}

Berbagai karakteristik sinyal lalulintas pada persimpangan yang harus sangat diperhatikan adalah sebagai berikut:

a. Waktu hijau

Waktu hijau untuk setiap fase dapat dihitung dengan menggunakan persamaan 3 .

$$
g_{i}=\left(C_{u a}-L T I\right) \times P R_{i}
$$

dimana:

$$
\begin{aligned}
g_{i}= & \text { waktu hijau dalam fase }-i \text { (detik) } \\
C_{u a}= & \text { waktu siklus yang ditentukan } \\
& \text { (detik) } \\
L T I= & \text { total waktu hilang per-siklus } \\
= & \Sigma(\text { allred }+ \text { amber }) i=\Sigma I G i \\
P R_{i}= & \text { perbandingan fase } \\
& F R_{C R I T} / \Sigma\left(F R_{C R I T}\right) \\
I G i= & \text { Waktu antar hijau pada pendekat } \mathrm{i}
\end{aligned}
$$

Waktu hijau yang lebih pendek dari 10 detik harus dihindarkan. Hal ini mungkin akan menghasilkan terlalu banyak pengemudi yang berlawanan setelah lampu merah dan kesulitan bagi pejalan kaki untuk menyeberang jalan.

\section{b. Waktu siklus sebelum penyesuaian}

Waktu siklus untuk fase dapat dihitung dengan persamaan 4. Waktu siklus hasil perhitungan ini merupakan waktu siklus optimum yang menghasilkan tundaan terkecil.

$$
C_{u a}=\frac{(1.5 \times L T I+5)}{(1-I F R)}
$$

dimana:

$$
\begin{aligned}
C_{u a}= & \text { waktu siklus sinyal (detik) } \\
L T I= & \text { total waktu hilang per-siklus } \\
& \text { (detik) } \\
I F R= & \text { perbandingan arus simpang } \\
& \sum\left(F R_{C R I T}\right)
\end{aligned}
$$

Fase sinyal yang menghasilkan nilai terendah dari $(I F R+L T I / c)$ adalah yang paling efisien. Waktu siklus yang disarankan oleh MKJI 1997, dapat dilihat pada tabel 1 .

Tabel 1. Waktu Siklus yang Disarankan

\begin{tabular}{|c|c|}
\hline $\begin{array}{c}\text { Tipe } \\
\text { kontrol }\end{array}$ & $\begin{array}{c}\text { Waktu siklus yang layak } \\
\text { (detik) }\end{array}$ \\
\hline 2 fase & $40-80$ \\
3 fase & $50-100$ \\
4 fase & $80-130$ \\
\hline
\end{tabular}

Sumber: Manual Kapasitas Jalan Indonesia 1997

Waktu siklus sangat berpengaruh terhadap kapasitas simpang. Namun harus dipertimbangkan, waktu siklus yang rendah akan mempersulit pejalan kaki untuk menyeberang jalan, sedangkan waktu siklus yang lebih besar dari yang disarankan harus dihindari kecuali untuk kasus yang sangat khusus.

\section{c. Waktu siklus yang disesuaikan}

Waktu siklus ini berdasar pada pembulatan waktu hijau yang diperoleh dan waktu hijau hilang $(L T I)$.

$$
c=\Sigma g+L T I
$$

\section{Kinerja Simpang}

Kualitas dari simpang dapat terlihat dari parameter-parameter berikut:

a. Kapasitas

Kapasitas pendekat simpang bersinyal menurut MKJI 1997 dapat dinyatakan dengan rumus 6 berikut:

$$
C=S \times g / c
$$

Dimana:

$$
\begin{aligned}
& C=\text { kapasitas (smp/jam) } \\
& S=\text { arus jenuh } \\
& g=\text { waktu hijau (det) } . \\
& c=\text { waktu siklus }
\end{aligned}
$$

\section{b. Derajat Kejenuhan}

Jika penentuan waktu sinyal sudah dikerjakan secara benar, derajat kejenuhan akan hampir sama dalam semua pendekat-pendekat kritis. Derajat kejenuhan diperoleh dengan rumus 7 berikut. 


$$
D S=Q / C=(Q \times c) /(S \times g)
$$

dimana:

$$
\begin{aligned}
Q & =\operatorname{arus~lalulintas}(\mathrm{smp} / \mathrm{jam}) \\
C & =\text { kapasitas }(\mathrm{smp} / \mathrm{jam})
\end{aligned}
$$

c. Perilaku lalulintas

Berbagai ukuran perilaku lalulintas yang juga mempengaruhi kualitas dari simpang adalah sebagai berikut:

1) Panjang Antrian

Jumlah rata-rata antrian kendaraan (dalam smp) pada awal sinyal hijau $(N Q)$ dapat dihitung dengan rumus 8 berikut:

$$
N Q=N Q_{1}+N Q_{2}
$$

Nilai $\mathrm{NQ}_{1}$ didapatkan dari:

Untuk $D S>0,5$

$$
N Q_{l}=0,25 \times C \times\left[(D S-1)+\sqrt{(D S-1)^{2}+\frac{8 \times(D S-0,5)}{C}}\right](9)
$$

Untuk $D S \leq 0,5$

$$
N Q_{1}=0
$$

Nilai $N Q_{2}$ didapatkan dari:

$$
N Q_{2}=c \times \frac{1-G R}{1-G R \times d s} \times \frac{Q}{3600}
$$

dimana:

$$
\begin{aligned}
N Q_{1}= & \text { jumlah smp yang tersisa dari } \\
& \text { fase hijau sebelumnya } \\
N Q_{2}= & \text { jumlah smp yang datang selama } \\
& \text { fase merah } \\
D S= & \text { derajat kejenuhan } \\
G R= & \text { rasio hijau }=g / c \\
c \quad= & \text { waktu siklus (detik) } \\
C \quad= & \text { kapasitas (smp/jam) }=S \times G R \\
Q \quad= & \text { volume lalulintas yang masuk di } \\
& \text { luar LTOR (smp/detik) }
\end{aligned}
$$

Panjang antrian $(Q L)$ diperoleh dari perkalian $(N Q)$ dengan luas rata-rata yang dipergunakan per smp $\left(20 \mathrm{~m}^{2}\right)$ dan pembagian dengan lebar masuk.

$$
\mathrm{QL}=\mathrm{NQ}_{\mathrm{MAX}} \times \frac{20}{\mathrm{~W}_{\text {MASUK }}}
$$

2) Tundaan

Tundaan rata-rata untuk suatu pendekat dihitung menggunakan rumus 13 berikut:

$$
D=D T+D G
$$

dimana:

$$
\begin{aligned}
& D=\text { Tundaan rata-rata untuk pendekat } \\
& \text { (det/smp) } \\
& D T=\text { Tundaan lalulintas rata-rata untuk } \\
& \text { pendekat (det/smp) } \\
& D G=\text { Tundaan geometri rata-rata } \\
& \text { untuk pendekat (det/smp) }
\end{aligned}
$$

Berdasarkan Akcelik (1988), tundaan lalulintas rata-rata pada suatu pendekat dapat ditentukan dari rumus 14 berikut:

$D T=c \times \frac{0,5 \times(1-G R)^{2}}{(1-G R \times D S)}+\frac{N Q_{1} \times 3600}{C}$

dimana:

$$
\begin{aligned}
D T= & \text { tundaan lalulintas rata-rata } \\
& (\text { det } / \mathrm{smp}) \\
c & \text { waktu siklus yang disesuaikan } \\
& (\text { det }) \\
G R= & \text { rasio hijau }(\mathrm{g} / \mathrm{c}) \\
D S= & \text { derajat kejenuhan } \\
N Q_{1}= & \text { jumlah smp sisa fase hijau } \\
& \text { sebelumnya } \\
C \quad= & \text { kapasitas (smp/jam) }
\end{aligned}
$$

Sedangkan besar nilai tundaan geometri ratarata $(D G)$ dihitung berdasarkan rumus:

$$
D G=\left(1-\rho_{S V}\right) \times \rho_{T} \times 6+\left(\rho_{S V} \times 4\right)
$$

dimana:

$$
\begin{aligned}
D G_{j}= & \text { tundaan geometri rata-rata } \\
& \text { untuk approach }(\mathrm{det} / \mathrm{smp}) \\
\rho_{S V}= & \text { rasio kendaraan terhenti } \\
& \text { pada } \text { approach } \\
\rho_{T}= & \begin{array}{l}
\text { rasio kendaraan berbelok pada } \\
\text { approach }
\end{array}
\end{aligned}
$$

Tundaan geometri rata-rata LTOR diambil sebesar 6 detik. Tundaan total (smp.det) didapatkan perkalian antara tundaan rata-rata dengan arus lalulintas $(D \times Q)$. Sedangkan tundaan rata-rata untuk seluruh simpang $\left(D_{1}\right)$ didapat dengan menggunakan rumus 16 berikut:

$$
D_{l}=\frac{\Sigma\left(Q \times D_{j}\right)}{Q_{T O T}}
$$




\section{III.Metodologi}

Secara keseluruhan, tahapan penelitian yang dilaksanakan dapat dilihat pada bagan alir pada Gambar 1.

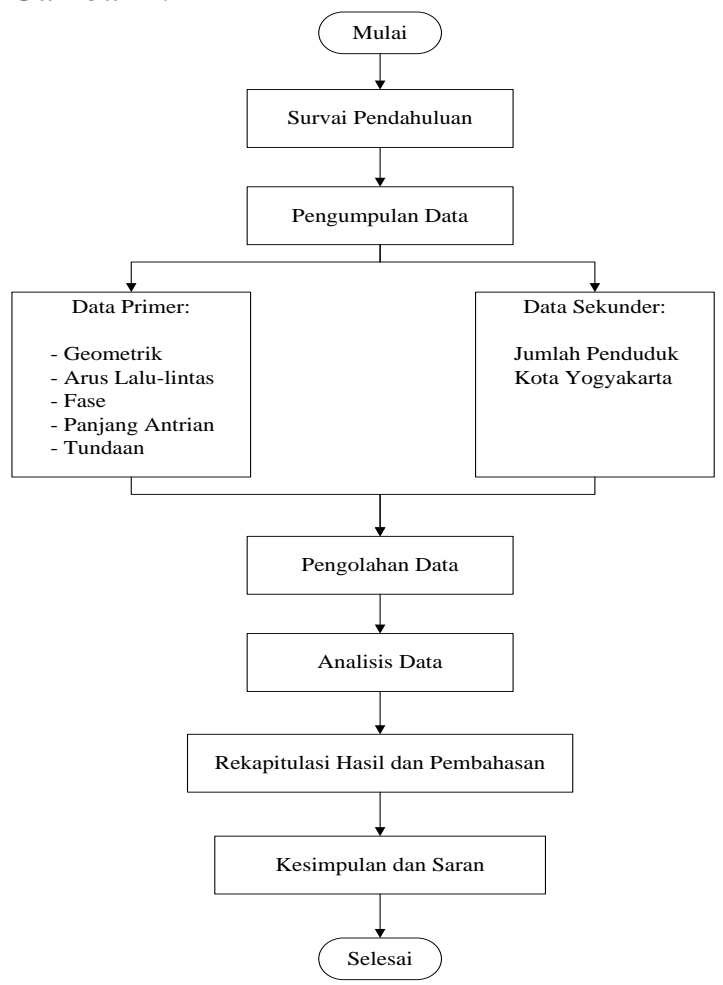

Gambar 1. Bagan alir penelitian

Simpang yang diteliti adalah Simpang Jetis yang merupakan simpang empat bersinyal. Simpang Jetis ini adalah persimpangan dari Jalan AM. Sangaji - Jalan Prof. Dr. Sarjito dan Jalan W. Monginsidi.

Data yang dibutuhkan adalah:

a. Kondisi geometrik jalan meliputi: jumlah lajur, lebar lajur, lebar lengan simpang dan lebar LTOR, median dan kelandaian.

b. Data volume kendaraan pada masingmasing lengan.

c. Data fase dan sinyal yang meliputi waktu siklus, waktu hijau aktual, waktu hijau efektif, waktu kuning, dan all red untuk masing-masing lengan.

d. Nilai panjang antrian pada masing-masing lengan

e. Nilai tundaan pada masing-masing lengan.

f. Data jumlah penduduk Kotamadya Yogyakarta.

Alat penelitian yang digunakan adalah formuir survey, hand counter, alat penunjuk waktu, roll meter dan kamera.
Setelah didapatkan data dari hasil survei yang dilakukan di lapangan, kemudian dilakukan hal-hal sebagai berikut:

1. Membuat rekapitulasi dari hasil perhitungan volume kendaraan di lapangan.

2. Melakukan perhitungan nilai volume dan kapasitas berdasarkan teori yang mengacu pada MKJI 1997.

3. Melakukan perhitungan panjang antrian di akhir periode merah (panjang antrian di awal periode hijau) dan nilai tundaan terukur di lapangan.

4. Membandingkan kinerja simpang secara praktis (yang terjadi di lapangan) dan secara teoritis (berdasarkan MKJI 1997) yang disajikan dalam bentuk tabel dan grafik.

\section{IV.Analisis dan Pembahasan}

1. Arus Jenuh

Dari hasil analisis terhadap kondisi di lapangan dan perhitungan dengan menggunakan MKJI 1997 terhadap kinerja Simpang Jetis, didapatkan perbandingan hasil arus jenuh seperti yang disajikan pada Gambar 2 berikut.

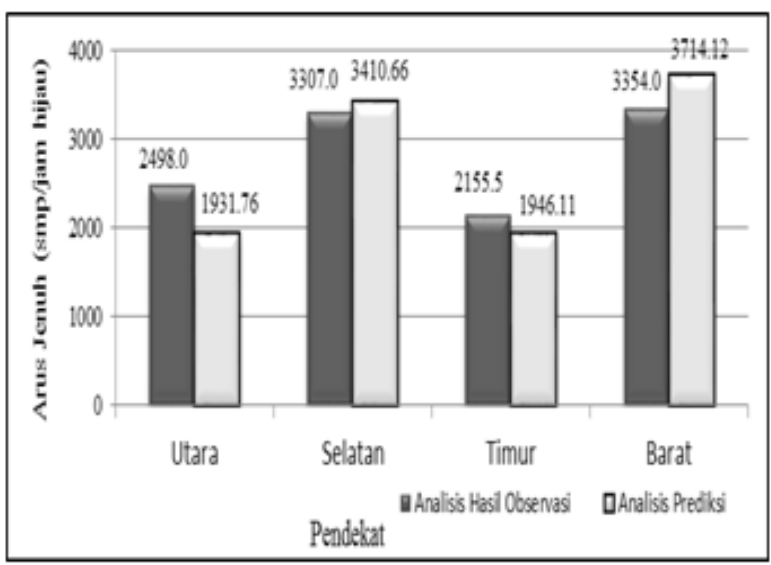

Gambar 2. Perbandingan Arus Jenuh

Dari grafik dapat terlihat arus jenuh yang didapatkan dari hasil observasi lapangan dengan hasil prediksi berdasarkan MKJI 1997 terdapat sedikit perbedaan namun tidak terlalu jauh. Untuk lengan utara dan timur, nilai arus jenuh yang terdapat di lapangan $29.31 \%$ dan $10.76 \%$ lebih tinggi dibandingkan prediksi. Sebaliknya untuk pendekat selatan dan barat, nilai arus jenuh di lapangan $3.04 \%$ dan $9.70 \%$ lebih rendah dibandingkan prediksi. 


\section{Waktu Sinyal}

Dari hasil analisis didapatkan penentuan nilai waktu sinyal untuk nyala hijau dan waktu siklus hasil perhitungan berdasarkan MKJI 1997 mempunyai nilai yang lebih rendah dibandingkan dengan nyala hijau dan waktu siklus yang diberlakukan di lapangan pada saat ini. Perbandingan waktu sinyal disajikan pada Tabel 2 berikut:

Tabel 2. Perbandingan Waktu Sinyal

\begin{tabular}{|c|c|c|c|c|}
\hline \multirow{2}{*}{ Pendekat } & \multicolumn{4}{|c|}{ Perbandingan Waktu Sinyal (detik) } \\
\cline { 2 - 5 } & Analisis Observasi Lapangan & \multicolumn{2}{|c|}{ Analisis Prediksi } \\
\cline { 2 - 5 } & Hijau, g & Siklus, $\mathrm{c}$ & Hijau, g & Siklus, $\mathrm{c}$ \\
\hline Utara & 35 & & 43 & \\
\hline Selatan & 34 & \multirow{2}{*}{143} & 28 & \multirow{2}{*}{132} \\
\cline { 4 - 5 } Timur & 25 & & 22 & \\
\hline Barat & 24 & & 19 & \\
\hline
\end{tabular}

Terdapat perbedaan waktu sinyal yang terdapat di lapangan saat ini dan prediksi berdasarkan MKJI 1997. Hal ini bisa dikarenakan penyesuaian terhadap sinyal akibat pertumbuhan arus pada setiap lengan yang terus meningkat dan berubah-ubah dari waktu ke waktu.

\section{Kinerja Simpang}

\section{a. Kapasitas}

Dari hasil analisis kapasitas terhadap kondisi di lapangan dan perhitungan dengan menggunakan MKJI 1997, didapatkan perbandingan nilai kapasitas yang disajikan pada Gambar 3 berikut:

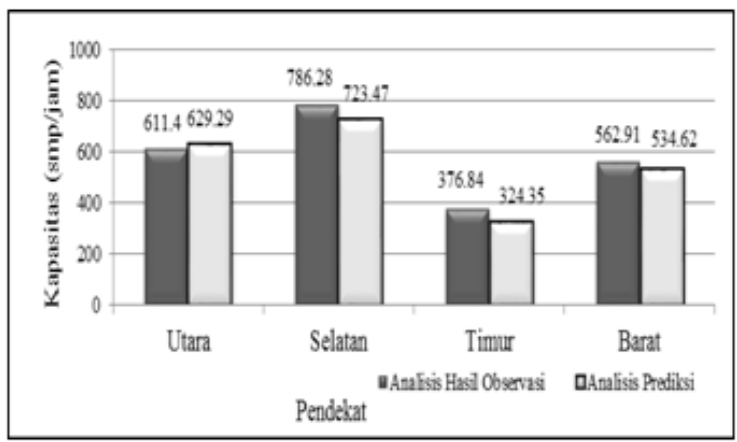

Gambar 3. Perbandingan Nilai Kapasitas

Dari grafik dapat terlihat bahwa kapasitas yang ada saat ini di lapangan hampir setara dengan prediksi berdasarkan MKJI 1997. Hanya terdapat sedikit perbedaan sekitar 3 sampai $8 \%$ untuk pendekat utara, timur dan barat, serta 16 $\%$ untuk pendekat selatan. Perbedaan ini dapat disebabkan perbedaan arus jenuh yang terdapat di lapangan dan hasil prehitungan MKJI 1997 dan dapat pula disebabkan oleh perbedaan waktu sinyal yang ditetapkan.

\section{b. Derajat Kejenuhan}

Dari hasil analisis derajat kejenuhan pada kondisi di lapangan dan perhitungan dengan menggunakan MKJI 1997, didapatkan perbandingan nilai derajat kejenuhan yang disajikan Gambar 4 berikut:

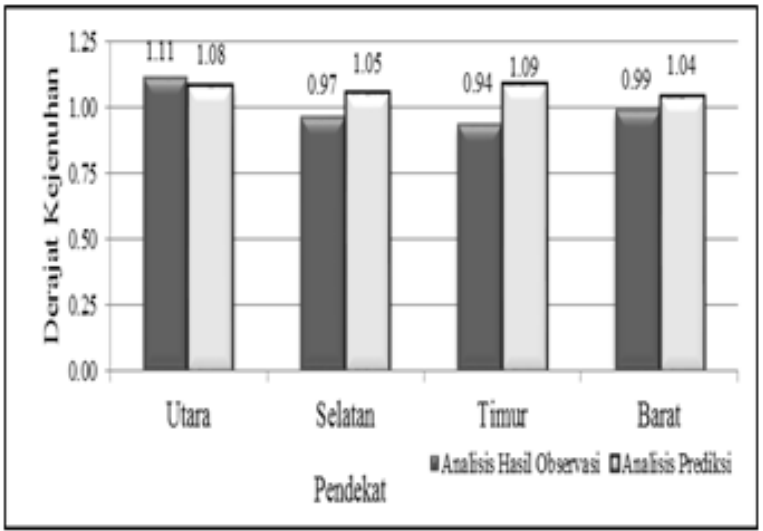

Gambar 4. Perbandingan Nilai Derajat Kejenuhan

Nilai deajat kejenuhan hasil analisis, baik dari hasil observasi lapangan maupun prediksi berdasarkan MKJI 1997 telah melampaui nilai derajat kejenuhan yang telah ditetapkan yaitu 0.85 . Hal ini berarti arus pada simpang sudah terlampau padat dan mengalami kemacetan lalulintas pada setiap pendekat. Hal ini bisa dikarenakan belum sesuainya pengaturan sinyal. Tapi apabila pengaturan sinyal sudah tepat maka perlu dievaluasi kembali lebar pada setiap pendekat dan pengaruh arus kendaraan berbelok.

\section{c. Perilaku Lalulintas}

1) Panjang Antrian

Perbandingan untuk jumlah antrian pada kondisi di lapangan dan perhitungan dengan menggunakan MKJI 1997 disajikan pada Gambar 5 berikut: 


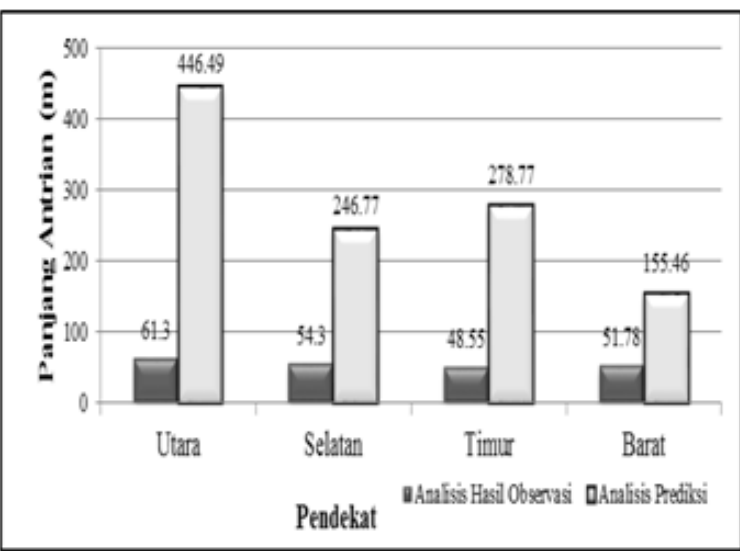

Gambar 5. Perbandingan Panjang Antrian

Dari grafik di atas dapat dilihat panjang antrian prediksi berdasarkan MKJI 1997 jauh lebih besar bila dibandingkan dengan jumlah dan panjang antrian yang terjadi di lapangan saat ini.

Besarnya panjang antrian terpengaruh dari pengaturan sinyal. Pengaturan sinyal tentu tidak dapat dipisahkan dari besarnya arus yang ada pada setiap pendekat. Semakin banyak kendaraan yang dapat dilewatkan pada saat nyala hijau, maka antrian kendaraan dapat diminimalisir. Tetapi jika kendaraan yang dapat melewati nyala hijau sedikit maka antrian kendaraan akan semakin besar.

2) Tundaan

Dari hasil analisis derajat kejenuhan pada kondisi di lapangan dan perhitungan dengan menggunakan MKJI 1997, didapatkan perbandingan nilai derajat kejenuhan yang disajikan pada Gambar 6 berikut:

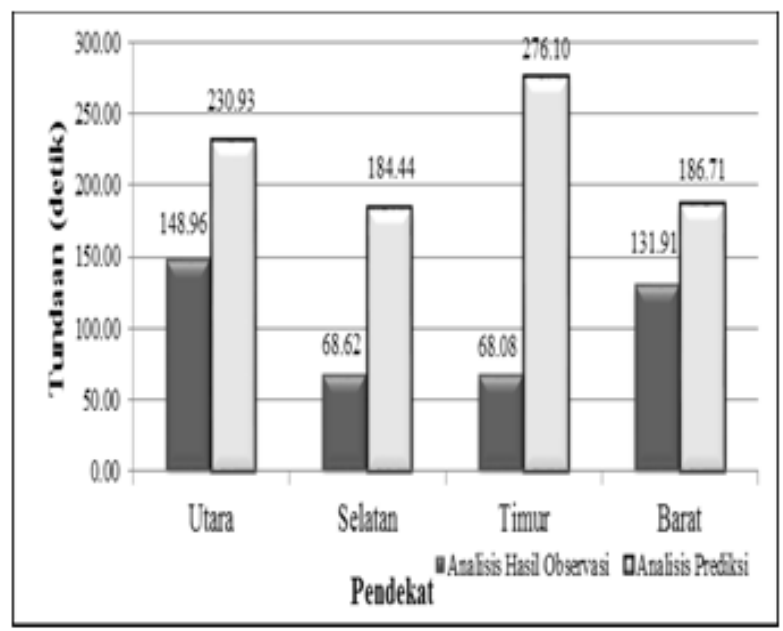

Gambar 6. Perbandingan Nilai Tundaan
Dari grafik dapat terlihat perbedaan nilai tundaan yang cukup jauh antara kondisi tundaan yang terdapat di lapangan saat ini dan tundaan yang di prediksi berdasarkan MKJI 1997. Perbedaan terbesar terdapat pada pendekat timur dengan tundaan di lapangan rata-rata adalah 68.08 detik sedangkan prediksi mencapai 276.10 detik.

\section{V.Kesimpulan}

Berdasarkan hasil pembahasan dan analisis pada bab sebelumnya, maka dapat ditarik beberapa kesimpulan sebagai berikut.

\section{Karakteristik Simpang Jetis}

Daerah Simpang Jetis merupakan simpang empat bersinyal yang berada pada lingkungan komersil dengan pendekat utara dan selatan (Jl. A. M Sangaji) merupakan jalan mayor. Simpang merupakan jenis 422 dengan pemberlakuan lajur khusus belok kiri (LTOR) pada lengan utara dan timur.

Arus terbesar pada simpang berasal dari pendekat utara dan selatan yang merupakan jalan mayor. Dari hasil observasi di lapangan dan analisis dengan menggunakan MKJI 1997 sebagai prediksi, nilai arus jenuh yang dapatkan hampir sama. Arus jenuh dari hasil observasi lapangan untuk pendekat utara, seatan, timur dan barat berturut-turut adalah 2498, 3307, 2155.5, dan 3354 smp/jam hijau. Sedangkan prediksi hasil perhitungan berturut-turut adalah 1931.76, 3410.66, 1946.11, dan 3714.12 smp/jam hijau.

Pergerakan pada simpang berputar sesuai dengan perputaran arah jarum jam. Sinyal yang digunakan adalah sinyal tiga warna dengan urutan merah-hijau kuning. Waktu siklus berdasarkan hasil observasi adalah 143 detik dan prediksi berdasarkan perhitungan dengan MKJI 1997 adalah 132 detik.

\section{Kinerja Simpang}

Dari hasil perbandingan analisis didapatkan sedikit perbedaan nilai kapasitas dan derajat kejenuhan. Perbedaan nilai kapasitas berkisar 3 sampai $8 \%$ untuk pendekat utara, timur dan barat, serta $16 \%$ untuk pendekat selatan. Perbedaan ini dapat disebabkan perbedaan arus jenuh dan dapat pula disebabkan oleh perbedaan waktu sinyal yang ditetapkan. 
Dari hasil observasi di lapangan didapatkan nilai derajat kejenuhan untuk pendekat utara, selatan, timur dan barat berturut-turut adalah 1.11, 0.97, 0.94 dan 0.99, sedangkan menurut prediksi adaah 1.08, 1.05, 1.09, dan 1.04. Dengan demikian hasil prediksi dikatakan dapat menggambarkan kondisi yang akan terjadi di lapangan. Namun seperti yang terdapat pada analisis, nilai derajat kejenuhan baik dari hasil observasi lapangan maupun prediksi berdasarkan MKJI 1997 telah melampaui nilai derajat kejenuhan yang telah ditetapkan yaitu 0.85 . Hal ini berarti arus pada simpang sudah terlampau padat dan mengalami kemacetan lalulintas pada setiap pendekat. Hal ini bisa dikarenakan belum sesuainya pengaturan sinyal. Tapi apabila pengaturan sinyal sudah tepat maka perlu dievaluasi kembali sistem manajemen lalulintas yang diberlakukan serta kondisi geometrik yang ada.

Hasil analisis perilaku lalulintas yang meliputi panjang antrian dan tundaan, didapatkan perbedaan yang sangat signifikan. Nilai tundaan dari hasil observasi lapangan untuk pendekat utara, seatan, timur dan barat berturutturut adalah 148.96 detik, 68.62 detik, 68.08 detik, dan 131.91 detik, sedangkan prediksi hasil perhitungan berturut-turut adalah 230.93 detik, 184.44 detik, 276.1 detik, dan 186.71 detik. Lamanya tundaan dapat disebabkan oleh pengaturan sinyal yang belum sesuai dengan kebutuhan arus yang ada pada setiap pendekat. Tapi jika pengaturan sinyal sudah tepat, maka besar kemungkinan kondisi geometrik simpang saat ini sudah tidak dapat melayani kebutuhan yang ada.

Untuk meningkatkan kapasitas dan pelayanan simpang, perlu dilakukan evaluasi kembali terhadap manajemen lalulintas yang diterapkan saat ini. Perlu dianalisis berbagai kemungkinan perubahan untuk meningkatkan nilai kapasitas dan pelayanan simpang, misalanya pelarangan arus kendaraan berbelok kanan. Apabila hal itu sulit, maka penambahan lebar untuk setiap pendekat mungkin harus dilakukan, namun hal ini akan membutuhkan biaya yang lebih besar.

\section{Daftar Pustaka}

Badan Pusat Statistik Provinsi D.I. Yogyakarta, (2009): http://yogyakarta.bps.go.id

Direktorat Jenderal Bina Marga, Departemen Pekerjaan Umum RI, (1997): Manual Kapasitas Jalan Indonesia. Jakarta.
Hobbs, F. D., (1995): Perencanaan dan Teknik Lalulintas, Edisi Kedua. Penerbit Universitas Gadjah Mada, Yogyakarta.

Menteri Perhubungan RI, (2006): Peraturan Menteri Perhubungan Nomor KM 14 Tahun 2006 tentang Manajemen dan Rekayasa Lalulintas Di Jalan.

Munawar, A. (2004): Manajemen Lalulintas Perkotaan, Edisi Pertama. Beta Offset, Yogyakarta. 